\title{
INTERNATIONAL COOPERATION OF BORDER SETTLEMENTS IN STRATEGIES FOR DEVELOPMENT OF SMALL AND SEMI-MEDIUM CITIES: CASE-STUDY OF KALININGRAD REGION (RUSSIAN FEDERATION)
}

\author{
AnNA Belova ${ }^{1}$ \\ Immanuel Kant Baltic Federal University (Russia)
}

\begin{abstract}
The role of cross-border cooperation of Kaliningrad region's of Russian Federation border municipalities in its development strategies are observed. Significance of cross-border cooperation of small and semi-medium cities for its socio-economic development is analysed. The main spheres of cooperation between small and semi-medium border settlements of Kaliningrad region, Poland and Lithuania have been defined. The theoretical base on cross-border cooperation (Russian and foreign researchers) was analysed, and five geographical methods were used on preparation the article.

KEY WORDS: development strategy, cross-border cooperation, border settlements, small and semi-medium-sized cities, socio-economic development.
\end{abstract}

JEL CODES: R120, R230, R500, R580, R590, O180, O190, F500, F590

\section{Introduction}

Kaliningad region of Russian Federation due to its geographical location has the exclave status for the country. And the cross-border cooperation of the Kaliningrad region with surrounding EU countries (Lithuania and Poland) plays significant role for socio-economic development of Kaliningrad region. It is important to mention that only Kaliningrad region is separated from Russian territory by other states. And the border regions of Russia consider the cross-border cooperation as one of the ways towards socio-economic development of the territory. Mostly small and semi-medium-sized cities are located along the borders of Russia, and its cooperation reflected in the development strategies of the border regions of the Russian Federation. Compared to other Russian peripheral territories, semi-medium sized cities of the Kaliningrad region actively participate in cross-border and transnational cooperation. All of them enjoy partnerships and twinning relationships with overseas neighbouring, and even with geographically remote cities. The strategies for socio-economic development of semi-medium sized cities of Kaliningrad region plays significant role for cross-border and trans-border cooperation for its development.

The main aim of the article is to analyse the strategies for socio-economic development of semi-mediumsized cities of Kaliningrad region on issue of the cross-border cooperation and to define main sectors for cooperation of semi-medium sized cities of Kaliningrad region with border municipalities of Lithuania and Poland. Also it is the objective to analyse the role of the border cities of Kaliningrad region for the settlement system o the region.

1 Anna Belova - Head of the European Union information center of the Immanuel Kant Baltic Federal University, Kaliningrad, scientific interests: social geography, international cooperation.

E-mail: polyotkina@mail.ru 


\section{Research review}

There are many Russian (Soviet) scientists have dealt with settlement systems, region planning and role of the settlements in socio-economic development of the territory. Among Russian scientists in this sphere it is needed to pay attention to economic geographers as B. S. Khoreev, S. G. Smidovich, G. M. Lappo, D. G. Khodzhaev, G. M. Fedorov (Lappo, 1997; Fedorov, 2001; Pustovgarov, Fedorov, 2001) and others. Among foreign scientists - W. Crystaller and A. Lesh, H. Hotellinag, J. Tunen, W. Laundhart, A. Weber and others (Simagin, 2009).

As soon as for border regions and territories, many scientists in their research work paid attention to border as the significant resource for improving the socio-economic situation in peripheral areas. There are such scientists as Russian (Soviet) geographers: P. Y. Baklanov, Y. N. Gladky, Y. M. Zverev, T. N. Chekalina, V. S. Korneevets, N. V. Kaledin, V. A. Kolosov, A. G. Manakov, B. B. Rodoman (Baklanov, Ganzej, 2004; Kaledin, Korneevets, Chekalina, 2008; Kolosov, Turovskij, 1998; Rodoman, 2002) and others; economists: O. V. Butorina, L. B. Vardomski, N. M. Mezhevich, N. Y. Oding (Mezhevich, 2002; Oding, Fedorov, 2009); politologs: I. N. Barygin, K. K. Khudoley, O. V. Plotnikova and others (Barygin, 2009; Plotnikova, 2005; Khudoley, Lanko, 2009).

Significant role plays the research works of such foreign scientists as E. Antola, E. Buchhover, V. Goermar, P. Joenniemi, U. Kivikari, M. Lindstrom, K. Lihuto, T. Palmovsky, E. Spiriajevas, I. Samson, F. Tassinari, H. Timmermann, K. Wellmann, J. Zaleski (Rosas, Antola, 1995; Buchover, 1994; Kivikari, Lindstrom, Liuhto, 1998; Palmowski, 2004; Spiriajevas, 2004; Timmermann, 2001; Tassinari, 2004).

As for the strategic planning for the regional development in boder regions and muniipalities, it is important to note such scientists as V. S. Bilchak, G. M. Fedorov, D. A. Bolotova, V. A. Lapina, V. Y. Liubovny, M. Y. Mahovej, N. M. Mezhevich, M. A. Nikolajeva, S. N. Yurkova (Bilchak, 2001; Fedorov, Zverev, Korneevets, 2008; Mezhevich, 2009; Shirokov, Yurkova, 2004) and others.

\section{Methodology}

During preparation of the present research the following methods used in research of social and economic geography have been applied (Djakonov, 1996):

- bibliographical method (study of works of Russian (soviet) and foreign geographers on the present subject);

- comparative and geographical method (to reveal general tendencies of social and economic development of the small and semi-medium-sized border cities and other border settlements of Kaliningrad region and border areas of Lithuania and Poland, and to analysis the strategic documents of the border municipalities of Kaliningrad region);

- method of spontaneous study of populated places (to reveal problems of border small and semi-medium cities of the Kaliningrad region);

- method of analysis of statistic data (to compose tables of forms and types of the crosborder cooperation of the border small and semi-medium cities of the Kaliningrad region with the view of their further analysis);

- cartographical method (aiming at presentation the border settlements of the region and adjacent EU states).

\section{Research results}

Regional strategies and policies of semi-medium sized cities and their adjacent areas were elaborated with regard to the specific geographical situation of the Kaliningrad region and the experience of cross-border and transnational cooperation. 
The Medium and Long-term Strategy for Socio-economic Development of the Kaliningrad region links the prospects of regional development to three interrelated problems (Strategy of soc. econ. develop. of Kaliningrad region, 2007):

1. Ensuring the Kaliningrad region's effective integration into chief socio-economic processes currently in progress in the Baltic region, with priority given to industrial-technological issues, transport, cultural development and migration issues. It requires synchronization of regional development both with closest neighbours and with other Russian regions.

2. Defining the role of the Kaliningrad region in achieving the strategic goals set on the Federal level viewed as an incentive for restructuring regional economies and for competitiveness enhancement.

3. Defining the baseline scenario of the EU-Russia relations development and the role of the Kaliningrad region in its implementation. Among the options considered there are: a) Russia's full membership in the EU; b) creation of a common market, including labour and capital markets, which suggests harmonization of Russian and European legislations; c) cooperation in several strategically significant areas (strategic partnership); e) maintenance of the status quo in the relationships.

Current socio-economic processes in the Baltic macro-region are regarded as fundamental factors of the regional development strategy in the Kaliningrad region. Along with the formation of a common market of labour, capital and transport services; together with technological upgrading, production management improvement (especially outsourcing, including the redistribution of businesses from the countries of old Europe to Poland and the Baltic States), we are witnessing the reform of general and vocational education, aimed at the formation of a common European space of higher education in the context of Bologna Process (Russia included). On top of this, great importance is attached to changes in migration issues and to the transformation of urban environment into a more environmentally - and investment-friendly milieu, with cities functioning as Pan-Baltic business centres or tourism hubs and emerging transnational urban agglomerations (Copenhagen-Malmo, in the long run - Tallinn-Helsinki) (Kaledin, Korneevets, Chekalina, 2008).

The Strategy emphasizes that "culture is becoming a factor of productivity growth and economic development, promoting an inflow of investments, mobile personnel, and information". It is these processes that account for a large share of tourism in the Baltic macro-region. The Kaliningrad region is facing the challenge to form a single tourist and recreational space jointly with some Polish and Lithuanian regions, and to enhance cross-border and international cooperation with the countries whose history is closely connected with the history of the area (including France, Holland, Italy, Austria, and the Czech Republic).

North-western Russian regions are also integrating into the spatial dimension of the Baltic region (Strategy of soc. econ. develop. of Kaliningrad region, 2007).

An example of cross-border collaboration is set by the Baltijsk municipality. Baltijsk, whose role until recently was limited to servicing the naval base, is now embarking on the path of developing civilian infrastructure, promoting SMEs, using its tourist potential, etc. Prospects for the district's advance are linked primarily to the development of port infrastructure and integration into the South Baltic Sea area transport system. The formation of the transport network in Baltijsk is remarkable for being part of the conversion process. The Ministry of Defence has already handed over two objects for civilian use (the third and fourth basins); two berths have been equipped for receiving ferries in Basin 3, and a ferry line has been launched with the itinerary Ust-Luga - St. Petersburg - Baltijsk. A railway terminal and a railway ferry service have been also launched, running Ust-Luga - Baltijsk - ports of Germany. A harbour station and a hydro-acoustic harbour are listed among prospective constructions.

The District Administration is determined to promote cross-border cooperation and to integrate into the world economy. The city is actively involved in relations with neighbouring cities (Strategy of soc. econom. development of Baltijsk, 2008).

Baltijsk's participation in the network of international transport corridors implies, above all, attracting freight and passenger flows and investment, business development, solution of acute social issues (including employment of laid-off officers to the reserve) and prevention of environmental pollution. On the whole, it 
will contribute to the prosperity of the Kaliningrad region, its socio-economic alignment with neighbouring countries and, ultimately, to the increase of living standards of its population.

It is the expansion and modernization of the Baltijsk port complex that is bound to boost competitiveness of Kaliningrad ports. It is necessary to build partnership relations between Kaliningrad and Klaipeda ports to set the specialization areas and ensure competitiveness for the cross-border consortium.

In the Baltijsk urban development strategy until 2015, cross-border issues are clearly set in the mission of the territory, stating that it is the Baltic sea gate of Russia and her outpost in the West; the key constituency in the development of the Kaliningrad region of the Russian Federation at the intersection of trade routes East-West, North-South; a centre for international cooperation, education, recreation, health improvement and tourism.

What accounts for most of the municipality's growth points is chiefly the function of servicing transit cargo and passenger flows, and simultaneous development of cross-border links with neighbouring regions, namely, Lithuania, Poland and Sweden (Strategy of soc. econom. development of Baltijsk, 2008).

The main advantage of the urban district of Svetly is its location along the Kaliningrad sea canal - the major infrastructural component of the transport complex in the Kaliningrad region, opening up the shortest way to the Baltic Sea, provided with equipped mooring lines, and offering a wide choice of transport communications (water, rail-, motor- ways), as well as the availability of developed transport infrastructure and several sea terminals. Among the noteworthy strengths of the district, are a number of major infrastructural facilities of regional significance located on its territory (JSC "Lukoil-Kalinigradmorneft", PLC "Commonwealth-Soya", PLC "Optim", etc.). A long-term cooperation with these enterprises is considered highly promising for the port. The district is also counting on benefits from the expansion of foreign economic relations and the growth of Russian exports. Another potential feature is vested in socio-economic cooperation with Kaliningrad, as well as with Russian and Polish settlements on the coast of the Vistula Bay (Strategy of soc. econom. development of Svetly, 2008).

As is stated in the mission, the Baltijsk district aims to form a modern urban industrial centre with the dominating role of a complex, embracing industrial (manufacturing) and freight handling facilities. In its strategy the District is not focused on the search of its own niche, but rather on the qualitative development of already emerging areas of specialization (Strategy of soc. econom. development of Baltijsk, 2008).

The urban districts of Svetly, as well as those of Baltijsk, Svetlogorsk, Guryevsk, Mamonovo, Bagrationovsk and the Zelenogradsky region (western part of the Kaliningrad region) in the long run could join the metropolitan area with its centre in the city of Kaliningrad.

In its development strategy, the Sovetsk urban district indicates among its internal strengths the proximity to the border equipped with crossing points, accessible external resources and a well-developed versatile industrial infrastructure. The participation in the Euro region "Saule" and other international projects; the district's tourist potential; its geographical location in the transport network both in the Kaliningrad region and prospective international corridors - these features add to the strengths of the district (Strategy of soc. econom. development of Sovetsk, 2009).

The district's external opportunities comprise: attraction of investments (including foreign ones) for the development of manufacturing, tourism, life-support systems and for implementing social programs; increasing its liaison function of the border and cross-border cooperation; location on the left bank of the River Neman, which is an international waterway; forwarding, warehousing, logistics and other services within servicing a newly built transportation corridor (Strategy of soc. econom. development of Sovetsk, 2009).

The Strategy for the medium- and long-term socio-economic development of the Kaliningrad region stresses that it is desirable to consider the potential of creating a strong freight-cargo hub on the basis of the conurbation 'Gusev - Cherniakhovsk', with the further relocation of logistics, sorting and the administrative centres for freight and rail haul to the hub. This measure would partially ease Kaliningrad's cargo transportation burden and thereby allow Kaliningrad to focus on specializations inherent in the capital city as a tourist and recreation centre, and a location of foreign and national businesses. This will also contribute to creating a more balanced spatial pattern of the Kaliningrad region, which now lacks the "second city" - the point 
of attraction for labour and production technologies (Strategy of soc.econ. develop. of Kaliningrad region, 2007; (Programme of soc. economic development of Kaliningrad region, 2006).

In the development strategy for the urban district of Cherniakhovsk, its international ties are regarded as one of the challenges whose solution is aimed at creating a favourable natural environment and at improving the quality of life (Strategy of soc. econom. development of Cherniakhovsk, 2009).

As points of growth the municipality specifically addresses two economic clusters: a transportation and logistics centre and the East-European Centre of horse husbandry. The transportation and logistics centre is defined as a facility unit for processing goods and for traffic servicing, which includes transportation networks (railways, roads), facilities infrastructure (warehouses, terminals) and services infrastructure (temporary storage warehouses, customs office, hotels, catering businesses, service stations). Although the transport sector of the Cherniakhovsk urban district is already an economic cluster, additional investments are badly needed into the accompanying infrastructure, such as logistics companies and hotel service (Strategy of soc. econom. development of Cherniakhovsk, 2009).

Gusev urban district also connects its prospects with the development of rail and road transport infrastructure and the Goldap-Gusev border crossing. Gusev is actively involved in cross-border cooperation projects under the neighbourhood programme including Lithuania, Poland, and the Kaliningrad region of Russia. The district is leading in a number of projects among municipalities, being engaged in attracting investments into processing industries (based on local resources) and agriculture. Currently, it is implementing the development of techno polis in partnership with I. Kant Baltic Federal University, and it also aims to develop cross-border cultural, historical and natural tourism. The municipality is actively working within the Euro region "Neman" (Programme for soc. econom. development of Gusev, 2009).

Analysing the cross-border cooperation of border cities (small and semi-medium-sized) of Kaliningrad region, sustainable networks have been established with small and medium-sized cities of the border countries - Lithuania and Poland (Table 1).

Table 1. Existing cross-border cooperation of the border small and semi-medium-sized cities of Kaliningrad region

\begin{tabular}{|l|l|l|l|}
\hline \multicolumn{1}{|c|}{ o } & \multicolumn{1}{|c|}{$\begin{array}{c}\text { Border city of } \\
\text { Kaliningrad region }\end{array}$} & $\begin{array}{c}\text { Cooperation border } \\
\text { country }\end{array}$ & $\begin{array}{c}\text { Cooperation border city } \\
\text { and sphere of cooperation }\end{array}$ \\
\hline 1 & Sovetsk & Lithuania & $\begin{array}{l}\text { Panemune (transport and logistic, culture, } \\
\text { tourism) } \\
\text { Shilale (Culture) } \\
\text { Pagėgiai (business, tourism, culture, youth } \\
\text { policy, sport) } \\
\text { Taurage (transport and logistic, business, } \\
\text { culture, tourism, youth policy, sport, } \\
\text { education) } \\
\text { Plunge (common food production } \\
\text { enterprise) }\end{array}$ \\
\hline 2 & Nesterov & $\begin{array}{l}\text { Virbalis (culture, education) } \\
\text { Kybartai (border crossing point, transport } \\
\text { and logistic) } \\
\text { Vilkaviškis (culture, entrepreneurship) }\end{array}$ \\
\hline 3 & Lithuania & $\begin{array}{l}\text { Siauliai, Taurage (within euro region } \\
\text { "Saule”, tourism, culture, environmental } \\
\text { protection) } \\
\text { Siauliai, Vilkaviškis, Kazlu Ruda, } \\
\text { Kalvarija, Marijampole, Jurbarkas (within } \\
\text { euroregion "Sheshupe", environmental } \\
\text { protection) }\end{array}$ \\
\hline
\end{tabular}




\begin{tabular}{|c|c|c|c|}
\hline № & $\begin{array}{c}\text { Border city of } \\
\text { Kaliningrad region }\end{array}$ & $\begin{array}{c}\text { Cooperation border } \\
\text { country }\end{array}$ & $\begin{array}{l}\text { Cooperation border city } \\
\text { and sphere of cooperation }\end{array}$ \\
\hline 4 & Svetlyj & Poland & $\begin{array}{l}\text { Svinoustje (tourism, environmental } \\
\text { protection) } \\
\text { Kalwarija Zebzhydovska (environmental } \\
\text { protection, tourism) } \\
\text { Novy Dwor Gdanski (culture, sport, } \\
\text { education) } \\
\text { Frombork (tourism, culture) } \\
\text { Kentrzyn (culture, sport, education, social } \\
\text { cooperation, environmental protection) } \\
\text { Common Union of the coastal gminas } \\
\text { of the Vistula lagoon (12 cities) for } \\
\text { development of the marine yacht tourism }\end{array}$ \\
\hline 5 & Ozersk & Poland & $\begin{array}{l}\text { Elk (agrotourism, culture, } \\
\text { entrepreneurship) } \\
\text { Ostroda (social sphere) } \\
\text { Sopot (social sphere, tourism) }\end{array}$ \\
\hline 6 & Gusev & Poland & $\begin{array}{l}\text { Goldap (culture, sports, social sphere, } \\
\text { tourism, environmental protection) } \\
\text { Pabjanice (culture, sport, social sphere) }\end{array}$ \\
\hline 7 & Baltijsk & Poland & $\begin{array}{l}\text { Elblag (transport, tourism, social sphere, } \\
\text { entrepreneurship) } \\
\text { Krynica Morska (transport, tourism) } \\
\text { Commun Union of the coastal gminas } \\
\text { of the Vistula lagoon (12 cities) for } \\
\text { development of the marine yacht tourism }\end{array}$ \\
\hline 8 & Mamonovo & Poland & $\begin{array}{l}\text { Branevo (environmental protection, } \\
\text { transport and logistic, social sphere) } \\
\text { Prabuty (social support of the local } \\
\text { inhabitants) } \\
\text { Pish (culture, entrepreneurship, tourism) } \\
\text { Penezhno (entrepreneurship, culture, } \\
\text { historical and cultural heritage) } \\
\text { Commun Union of the coastal gminas } \\
\text { of the Vistula lagoon (12 cities) for } \\
\text { development of the marine yacht tourism }\end{array}$ \\
\hline 9 & Bagrationovsk & Poland & $\begin{array}{l}\text { Lidzbark (social sphere, education, culture, } \\
\text { sport, youth policy, entrepreneurship, } \\
\text { cooperation between non-governmental } \\
\text { organisations) } \\
\text { Korshe (culture, tourism) } \\
\text { Bartoszyce (transport and logistic, } \\
\text { entrepreneurship, culture, environmental } \\
\text { protection, tourism) } \\
\text { Ilawa (culture, social sphere, } \\
\text { entrepreneurship) }\end{array}$ \\
\hline
\end{tabular}

Sourse: Prepared by Author

According to the spheres of cross-border cooperation of small and semi-medium sized cities with neighbouring border cities of Poland and Lithuania, culture and tourism are in leader position (Fig. 1). 


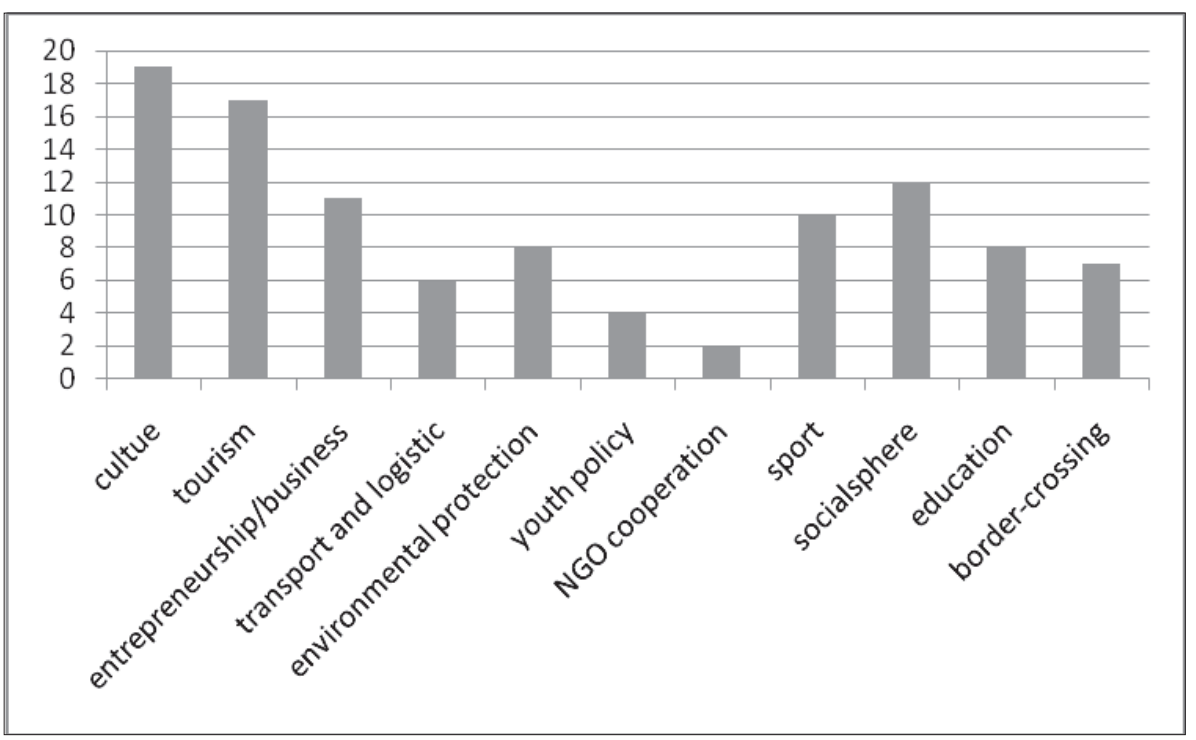

Figure 1. Cooperation spheres of the border cities of Kaliningrad region of RF, Lithuania and Poland Source: Prepared by Author

According to the Fig.1, as it was mentioned above, culture and tourism are leaders of cooperation of the border cities. Also, social sphere, sport and entrepreneurship have significant role in cross-border cooperation. NGO cooperation is not well-developed, but thanks to euro regional cooperation and such cooperation tool as Cross-border cooperation Programme Lithuania-Poland-Russia 2007-2013, there are more and more NGO establishing and start to cooperate.

\section{Conclusions}

Every semi-medium sized town of the Kaliningrad region benefits from of its geographical location and economic situation. It is these benefits that predetermined the growth in the size of these towns compared to other municipal town of the region (excluding the city of Kaliningrad) and created the necessary prerequisites for their further dynamic development. These prerequisites can be realized under several conditions, if the Kaliningrad region (as it can be expected) starts to play a more important role in international economic relations of Russia, and if Russia's economy continues its rapid development. Secondly, if industrial cooperation develops in the south-east of the Baltic Sea region, thus forming a single territorial Russian-PolishLithuanian economic system, called "Trehgradie" (Gdansk - Gdynia - Sopot - Kaliningrad - Klaipeda). Apart from it, a lot depends on the growth in the labour recourses of the Kaliningrad region as a result of the implementation of the programme of re-settlement of Russian citizens, who now live abroad, in the Kaliningrad region. Another condition is to be fulfilled - the development of transport infrastructure, including extensive development of the rail roads and highways, connecting the Kaliningrad region with other Russia regions and European countries. The ports of the Kaliningrad region are to increase their capacity.

Baltijsk and Svetly, being Kaliningrad Avant posts, are parts of the Kaliningrad agglomeration and the Kaliningrad transport junction. The development of these two towns as satellites of Kaliningrad should be closely connected with the development of the whole agglomeration, its industrial and, to a greater extent, social infrastructure, as well as its rapid changes in labour recourses and the necessity to solve common environmental problems. Cross-border cooperation of these cities with border cities of neighbouring states is mostly connected with transport and logistic, and sports and social sphere.

Cherniakhovsk and Gusev trend to create a single territorial system, developing as one whole. These towns could counterbalance further concentration of the industrial potential in the west of the Kaliningrad 
region. From the point of view of the development of urban-rural partnership, Cherniakhovsk plays an important role in agro-industrial cooperation and providing services to the rural population in the south-east of the region. Cherniakhovsk, developing its integration with Gusev and forming a single territorial system, may become even more active in providing services to the neighbouring rural population.

Sovetsk can use the advantages of its proximity to the border for further strengthening its economic ties with the neighbouring districts of Lithuania. While developing, Sovietsk may include Neman and Slavsk into the sphere of its influence, thus creating a small agglomeration in the north of the Kaliningrad region. As soon as Sovetsk is one of the biggest border-crossing point, which is significant not only for Kaliningrad region, but also for Russia, the transport and logistic are main cooperation sphere with neighbouring Lithuanian settlements. Other significant cooperation spheres' are: entrepreneurship, social sphere, culture and tourism. Also Nesterov and Chernyshevskoje settlement of Kaliningrad region are cooperate with Lithuanian border settlements first of all as crossing-border points, and within different social spheres.

The cross-border cooperation of small and semi-medium-sized cities of Kaliningrad region and border states - Lithuania and Poland strengthening from year to year. People-to-people contacts of the border settlements also rising up. This is possible due to cooperation tools such as euroregional cooperation and cooperation Programmes (CBC ENPI Lithuania-Poland-Russia 2007-2013, Baltic Sea Region Programme 2007-2013 and South Baltic Programme), and also due to significant role of cross-border cooperation in development strategies of border cities and municipalities, as well as the Kaliningrad region as a whole.

Cross-border cooperation of border cities of Kaliningrad region with Lithuanian and Polish ones is very important for regional socio-economic development. It allows experiencing exchange and to get and implement the best practices in different spheres, such as environmental protection, innovative industry, social sphere, education, etc.

It is necessity improving the socio-economic situation of the border areas due to opening the small crossborder movement between Poland and Kaliningrad region.

Further coordination of the development strategy of the Kaliningrad region and its municipalities with the development strategies of the neighbouring Baltic Sea region countries will definitely facilitate positive trends in the development of semi-medium sized towns and the Kaliningrad region as a whole.

\section{References}

Buchover, E. (1994). Die Neuorientierung der Aussenhandelstrome in ihrer Auswirkung auf die wirtschaftlichen Binnenstrukturen Polens und der baltischen Staaten. Neuorientierung der Aussenwirtschaftsbeziehungen in Ostmitteleuropa. Wirtschafts- und Sozialwissenschaftliche Ostmitteleuropa-Studien, Vol. 20, S. 131-140.

Kivikari, U., Lindstrom, M., Liuhto, K. (1998). The external economic relations of the Kaliningrad Region. Turku school of economics and business administration. Discussion C2.

Rosas, A., Antola, E. (eds.) (1995). A Citizens Europe: in Search of a New Order, p. 32-44.

Tassinari, F. (2004). Mare; Europaeum: Baltic: Seat Region Security and Cooperation frompost-Wall to post-Enlargement Europe. Copenhagen. University of Copenhagen, 70 p.

Timmermann, H. (2001). Kaliningrad: eine Pilotregion fur Gestaltung der Partnerschaft EU - RuSland? Osteuropa, Vol. 51, p. 1036-1066.

Zaleski, J. (2006). Together or separately? A contribution to the concept of Baltic region commonwealth. Baltic Europe. From Idea to Reality. Coastal Regions, Vol. 11, p. 9-31.

Бакланов, П. Я., Ганзей, С. С. (2004). Приграничные и трансграничные территории как объект географических исследований. Вестник СПбГУ. Геология, география, №. 4, с. 27-34.

Барыгин, И. Н. (2009). Международное регионоведение. СПб. Питер, 384 с.

Бильчак, В. С. (2001). Приграничная экономика. Монография. Калининград. Изд-во КГУ, 372 с.

Дьяконов, К. Н., Касимов, Н. С., Тикунов, В. С. (1996). Д93 Современные методы географических исследований: Кн. для учителя. Москва: Просвещение. АО «Учеб. лит.», 207 с.

Каледин, Н. В., Корнеевец, В. С., Чекалина, Т. Н. (2008). Сетевое сотрудничество как основополагающий фактор формирования трансграничных регионов. Вестник СПбГУ. Геология, география, o. 4, с. 130-139.

Колосов, В. А., Туровский, Р. Ф. (1998). Современные государственные границы: новые функции в условиях интеграции и приграничное сотрудничество. Известия Геология, география, №. 1, с. 106-113. 
Лаппо, Г. М. (1997). География городов: Учеб. пособие для геогр. ф-тов вузов. Москва: Гуманит. изд. центр ВЛАДОС, с. 48-102.

Межевич, Н. М. (2009). Приграничное сотрудничество и практика деятельности Еврорегионов на СевероЗападе России и в Республике Беларусь. Информационное бюро Совета Министров Северных стран в Санкт-Петербурге, 268 с.

Межевич, Н. М. (2002). Региональная экономическая политика Российской Федерации: влияние трансграничного сотрудничества на традиционные и новые механизмы реализациии. СПб. Изд-во СПбГУ.

Одинг, Н. Ю, Федоров, Г. М. (2009). Трансграничное сотрудничество на Балтике как фактора перехода экономики сотрудничающих регионов на инновационный путь развития. Исследования.Балтийского региона, №. 1, с. 19-27.

Официиальный сайт Администрациии мунициипального образования «Багратионовский муниципальный район»: http://bagrationovsk-mo.ru/

Офицчиальный сайт Администрацчии муницุипального образования «Мамоновский городской округ»: http://mamonovo.gov39.ru

Официиальный сайт Администрацчии муницииального образования «Неманский муниципальный район»: httр:// neman.gov39.ru

Официальный сайт Администрации муниципального образования «Нестеровский район»: http://www.admnesterov.ru/

Офиичильный сайт Администраичи муниципального образования «Озерский район»: http://www.ozyorsk.ru/

Пальмовский, Т. (2004). Новая Балтийская биполярная модель межрегионального сотрудничества. Вестник Калининградского государственного университета. Регионоведение, №4, с. 66-75.

Плотникова, О. В. (2005). Международное сотрудничество регионов: кониептуальные подходы. Новосибирск. Изд-во СО РАН, 356 с.

Программа социильно-экономического развития Калининградской области на 2007-2016 годыl. (2006). http:// www2.gov39.ru/index.php?idpage $=563$

Программа социально-экономического развития муниципального образования «Гусевский муниципальный район» на 2009-2016 годы. (2009). Гусев.

Пустовгаров, В. И., Федоров, Г. М. (2001). Государственное регулирование системы расселения Калининградской области. Калининград. Изд-во КГУ, с. 4-41.

Родоман, Б. Б. (2002). Государственные границы в СНГ и приграничная политика. Поляризованная биосфера: сборник статей. Смоленск. Ойкумена, с. 198-202.

Симагин, Ю. А. (2009). Территориальная организащия населения и хозяйства. Учебное пособие. Москва: КноРус, с. 136-149.

Спиряевас, Э. (2004). Туризм как перспективное направление в приграничном сотрудничестве на территории Куршского залива. Российская Балтика: приграничное сотрудничество. Калининград, с. 186-201.

Стратегия социально-эконолического развития Калининградской области на средне- и долгосрочную перспективу. (2007). http://www2.gov39.ru/index.php?idpage=563

Стратегия сочиально-экономического развития муниципального образования «Балтийский городской округ» на период до 2016 года. (2007). Калининград.

Стратегия социально-экономического развития муниципального образования «Светловский городской округ» на период до 2016 года. (2008). Светлый.

Стратегия соичильно-экономического развития муниципального образования «Советский городской округ» на период до 2016 года. (2009). Советск.

Стратегия социально-экономического развития муниципального образования «Черняховский городской округ» на период до 2016 года. (2009). Черняховск.

Федоров, Г. М. (2001). Население Калининградской области. Демографические условия обоснования Территориальной комплексной схемь градостроительного планирования развития территории Калининградской области и ее частей: Монография. Калининград: Изд-во КГУ, с. 24-39.

Федоров, Г. М., Зверев, Ю. М., Корнеевец, В. С. (2008). Россия на Балтике: 1990-2007 годы. Калининград: Издво РГУ им. И. Канта, 224 с.

Худолей, К. К., Ланко, Д. А. (2009). Санкт-Петербург в Балтийском регионе. Балтийский регион, Vol. 1, с. 64-76.

Широков, А. Н., Юркова, С. Н. (2004). Федеральное законодательство России о местном самоуправлении. Москва, 78 с. 


\title{
TARPTAUTINIS PASIENIO GYVENVIEČIUQ BENDRADARBIAVIMAS MAŽŲ IR VIDUTINIŲ MIESTŲ VYSTYMO STRATEGIJOSE: KALININGRADO SRITIES PAVYZDYS (RUSIJOS FEDERACIJA)
}

\author{
AnNA Belova \\ Emanuelio Kanto Baltijos federalinis universitetas (Rusija)
}

\section{Santrauka}

Kaliningrado regionas yra Rusijos Federacijos eksklavas, todėl pasienio bendradarbiavimas su jị supančiomis ES šalimis (Lietuva ir Lenkija) ypač svarbus socioekonominiam regiono vystymuisi. Kaliningrado regione yra devyni vidutiniai pasienio miestai, kurie, kaip ir kiekviena gyvenviete, regione išnaudoja savo geografinès padèties privalumus.

Baltijskas ir Svetly yra Kaliningrado aglomeracijos ir transporto mazgo dalis. Šių dviejų miestų vystymasis labai priklauso nuo visos aglomeracijos vystymosi tendencijų. Šių miestų bendradarbiavimas su kaimyninių valstybių pasienio miestais daugiausia susijęs su transportu, logistika, sportu ir socialiniais ryšiais.

Černiachovskas ir Gusevas sudaro vieningą teritorinę sistemą ir vystosi kartu. Šie du miestai gali išlyginti šiuo metu pastebimą pramonès susitelkimą Kaliningrado regiono vakaruose. Černiachovskas vaidina svarbu vaidmeni plètojant agropramoninị bendradarbiavimą ir teikiant paslaugas pietrytinei regiono daliai.

Sovetskas gali pasinaudoti pasienio teikiamais privalumais ir toliau stiprinti ekonominius ryšius su kaimyniniais Lietuvos regionais. Besivystantis Sovetskas gali itraukti Nemano ir Slavsko miestus i savo itakos zoną, taip sukurdamas nedidelę aglomeraciją regiono šiaurėje. Transportas ir logistika yra pagrindinės bendradarbiavimo su kaimyniniais Lietuvos regionais sritys, kitos svarbios sritys yra verslas, socialinė sritis, kultūra ir turizmas.

Kaliningrado regiono, Lietuvos ir Lenkijos pasienių bendradarbiavimas metams bėgant darosi vis aktyvesnis. Žmonių bendravimas pasienyje taip pat aktyvejja, tam labai padeda bendradarbiavimą skatinančios programos (tokios kaip CBC ENPI Lithuania-Poland-Russia 2007-2013, Baltic Sea Region Programme 2007-2013, South Baltic Programme), pasienio miestu, savivaldybių ir regionu plètros strategijos, kur pasienio bendradarbiavimui skiriamas didelis dėmesys. Pasienio bendradarbiavimas leidžia keistis patirtimi ivairiose srityse, tokiose kaip aplinkosauga, moderni pramonė, socialinè sritis, švietimas ir pan.

Tolesnis Kaliningrado srities ir jos savivaldybių vystymo strategijų koordinavimas su kaimyninių Baltijos jūros regiono valstybių vystymo strategijomis, paskatins smulkių ir vidutinių miestų bei viso Kaliningrado regiono tolesni vystymąsi.

PAGRINDINIAI ŽODŽIAI: vystymo strategija, pasienio bendradarbiavimas, pasienio gyvenvietės, maži ir vidutiniai miestai, socioekonominis vystymasis.

JEL KLASIFIKACIJA: R120, R230, R500, R580, R590, O180, O190, F500, F590 